\title{
INVESTIGATION OF THE COMPOSITION OF ACTIVE PHARMACEUTICAL INGREDIENTS IN “APISED” CAPSULES BY THE METHOD OF HIGH PERFORMANCE LIQUID CHROMATOGRAPHY
}

\author{
O.S.Shpychak, O.I.Tikhonov \\ National University of Pharmacy \\ Key words: terpenoids; flavonoids; essential oils; high-performance liquid chromatography
}

As high-performance liquid chromatography is the most optimal method for qualitative and quantitative analysis of multicomponent medicines, including phytomedicines, - owing to the possibility to identify and quantify the substances of different volatility degree in the same sample, - the qualitative composition and quantitative content of the complex apiphytomedicine "Apised" developed in the form of capsules for treatment of mental and emotional disorders and depression states in sports medicine has been investigated using HPLC-analyser on the basis of a Milichrome A-02 chromatograph. At the preliminary stage of our research of the active pharmaceutical ingredients of "Apised" capsules and the apiphytomedicine directly developed it has been found that there are 14 compounds in the composition of the standardized substance of natural powdered honey, 19 compounds in the composition of the garden balm herb, 24 compounds in the composition of the hop cones, 20 compounds in the composition of the inflorescences of spike lavender, 27 compounds in the composition of "Apised" capsules. By comparing the retention times and spectral ratios of the peaks obtained with the device database the presence of linalool, rosmarinic and chlorogenic acids in the composition of the garden balm herb, quercetin and myrcene in the composition of the hop cones, linalool in the composition of the inflorescences of spike lavender, linalool and myrcene in the composition of natural powdered honey has been shown. The experimental data concerning the percentage of biologically active substances in the apiphytomedicine "Apised" correlate well with the composition of the medicine developed and the literary information about the chemical composition of the medicinal plant raw material studied. The method offered gives the possibility to carry out standardization of the composition of the medicine developed, namely "Apised" capsules, regardless of the way of obtaining and origin of the medicinal plant raw material.

To treat mental and emotional disorders and depressions states in sports medicine the complex apiphytomedicine "Apised" in the form of capsules [2] has been developed at the Department of Pharmacy Technology of Drugs of the National University of Pharmacy; its main active pharmaceutical ingredients $(\mathrm{APhI})$ are the standardized substance of natural powdered honey (NPH) and the essential oil plant raw material such as the garden balm herb (Herba Melissa officinalis), the hop cones (Strobuli Humuli lupuli) and the inflorescences of spike lavender (Flores Lavandulae angustifoliae) [5].

As high-performance liquid chromatography (HPLC) is considered to be the most optimal method for qualitative and quantitative analysis of multicomponent medicines, including phytomedicines $[6,10,12]$, we have set a goal to carry out the research of the apiphytomedicine developed just by this method.

Previously the qualitative composition and quantitative content of the main components of essential oils of $\mathrm{APhI}$ of "Apised" capsules was investigated by us using the method of gas chromatography, however, the method developed allows to determine only volatile compounds included in the composition of the medicine [11].

Unlike other research methods of biologically active compounds the advantage of HPLC method con- sists exactly in the possibility to identify and quantify the substances of different volatility degree in the same sample under the chromatographic conditions carefully selected. The presence of such conditions is provided by using the so-called HPLC-analyser - it is the approach, which essence consists in carrying out the analysis of compounds of a certain list (from 20 to 500 substances) using the same chromatographic system. For this purpose the database for the array of standard substances is compiled, and futher identification of peaks on chromatograms of the test samples is carried out by comparison of their retention times, as well as spectral ratios with this database $[7,9,10]$. One of the variants of such a system was developed on the basis of a Milichrome A-02 chromatograph ("EcoNova" JSC, Novosibirsk, Russian Federation) [1] are among them.

In the work the results of determination of biologically active substances of "Apised" capsules and their individual ingredients using the system of HPLC-analyser mentioned have been given.

\section{Materials and Methods}

The following samples of APhI of "Apised" capsules as the garden balm herb - Herba Melissa officinalis $L$. (the registration certificate No. UA/8919/01/01, batch 60612) manufactured by "Liktravy" PJSC (Zhy- 
The basic chromatographic parameters of linalool, myrcene, rosmarinic acid, quercetin and chlorogenic acid when determining by the HPLC method

\begin{tabular}{|l|c|c|c|c|c|c|c|c|c|c|}
\hline \multirow{2}{*}{ Substance } & \multirow{2}{*}{$t_{R^{\prime}} \min$} & \multirow{2}{*}{$V_{R^{\prime}} \mathrm{mcl}$} & \multicolumn{7}{|c|}{$R\left(S_{\lambda} / S_{210}\right)$} \\
\cline { 4 - 11 } & & & $\frac{210 \mathrm{~nm}}{210 \mathrm{~nm}}$ & $\frac{220 \mathrm{~nm}}{210 \mathrm{~nm}}$ & $\frac{230 \mathrm{~nm}}{210 \mathrm{~nm}}$ & $\frac{250 \mathrm{~nm}}{210 \mathrm{~nm}}$ & $\frac{260 \mathrm{~nm}}{210 \mathrm{~nm}}$ & $\frac{270 \mathrm{~nm}}{210 \mathrm{~nm}}$ & $\frac{280 \mathrm{~nm}}{210 \mathrm{~nm}}$ & $\frac{330 \mathrm{~nm}}{210 \mathrm{~nm}}$ \\
\hline Chlorogenic acid & 9.46 & 9460 & 1.0000 & 0.8780 & 0.6022 & 0.1537 & 0.2095 & 0.2248 & 0.2473 & 0.5247 \\
\hline Rosmarinic acid & 12.53 & 1253 & 1.0000 & 0.8647 & 0.6565 & 0.5564 & 0.4277 & 0.3956 & 0.4905 & 0.9269 \\
\hline Quercetin & 14.16 & 1416 & 1.0000 & 0.6439 & 0.4958 & 0.1953 & 0.1232 & 0.1612 & 0.2840 & 0.4679 \\
\hline Linalool & 20.76 & 2076 & 1.0000 & 0.5252 & 0.4020 & 0.8165 & 0.8135 & 0.5118 & 0.4426 & 0.6019 \\
\hline Myrcene & 27.20 & 2720 & 1.0000 & 0.7997 & 0.6846 & 0.6533 & 0.4298 & 0.3127 & 0.3253 & 0.7136 \\
\hline
\end{tabular}

tomyr, Ukraine); the hop cones - Strobuli Humuli lupuli L. (the registration certificate No.UA/11477/01/01, batch 003) manufactured by "Liktravy" PJSC (Zhytomyr, Ukraine); the inflorescences of spike lavender - Flores Lavandulae angustifoliae Mill. cultivated on the territory of Nikitsky Botanical Garden of UAAS; NPH (amendment No.1:2013 to the Ukrainian specification 01.2-02010936-001:2007) obtained by freeze drying under conditions of "Biolik" JSC (Kharkiv) using the "Virtis" production equipment (USA); as well as "Apised" capsules $[2,5]$ were the objects of our research.

The standard samples of compounds such as linalool (batch W263516), myrcene (batch 64643), rosmarinic acid (batch 00390580) produced by Sigma-Aldrich Chemie GmbH company (Germany) and pharmacopeial standard samples of quercetin (batch 050107) and chlorogenic acid (batch 140308) were used in our work.

The chromatographic procedure was carried out using a Milichrome A-02 chromatograph.

The chromatographic conditions were:

- column - $\varnothing 2 \times 75 \mathrm{~mm}$;

- reversed phase - ProntoSIL - $120-5-\mathrm{C} 18 \mathrm{AQ}$ ("Bischoff Analysentechnik und Geräte GmbH", Germany);

- efficiency - not less than 5000 theoretical plates;

- temperature $-40^{\circ} \mathrm{C}$;

- eluent $\mathrm{A}$ - $\left[4\right.$ mole/1 $\mathrm{LiClO}_{4}-0.1$ mole/ $\left./ \mathrm{HClO}_{4}\right]$ $\mathrm{H}_{2} \mathrm{O}(5: 95)$;

- eluent B - acetonitrile "for HPLC";

- flow rate $-100 \mathrm{mcl} / \mathrm{min}$;

- elution - a linear gradient from 5\% to $100 \%$ of acetonitrile for $40 \mathrm{~min}$, then $100 \%$ acetonitrile for $3 \mathrm{~min}$; - detector - UV-spectrophotometer with 8 wavelengths $(210,220,230,250,260,270,280$ and $330 \mathrm{~nm})$.

The chromatographic HPLC-system suitability is periodically controlled by chromatographing the special control multicomponent solution.

The sample preparation was carried out in the following way: $0.2000 \mathrm{~g}$ of the corresponding test sample was extracted by $20.00 \mathrm{ml}$ of $96 \%$ ethanol; the solutions obtained were filtered and analysed under the conditions mentioned above; not less than 5 chromatograms were developed - the sample volume was $4 \mathrm{mcl}$.

\section{Results and Discussion}

At the preliminary stage of our research of the active pharmaceutical ingredients of "Apised" capsules and the apiphytomedicine directly developed it has been found that there are 14 compounds in the composition of the standardized substance of natural powdered honey, 19 compounds in the composition of the garden balm herb, 24 compounds in the composition of the hop cones, 20 compounds in the composition of the inflorescences of spike lavender, 27 compounds in the composition of "Apised" capsules.

By comparing the retention times and spectral ratios of the peaks obtained with the device database the presence of linalool, rosmarinic and chlorogenic acids in the composition of the garden balm herb, quercetin and myrcene in the composition of the hop cones, linalool in the composition of the inflorescences of spike lavender, linalool and myrcene in the composition of natural powdered honey has been shown.

To increase reliability of identification of the compounds previously determined the standard samples (SS) of linalool, myrcene, quercetin, rosmarinic and chlorogenic acids added to the test samples after the primary identification were used, and the repeated research was conducted.

Increase of the peak area of the corresponding compounds and the absence of peaks split in this case confirm the supposition concerning the structure of the compounds identified made during the primary analysis.

The basic chromatographic parameters of the compounds identified under the conditions of performing the analysis are given in Tab. 1.

The typical chromatogram of biologically active compounds of the apiphytomedicine "Apised" obtained under conditions of the experiment is given in Figure.

For quantitative determination of the substances identified in the composition of $\mathrm{APhI}$ of the apiphytomedicine studied and namely "Apised" capsules at the first stage of the experimental research the batch of model solutions of linalool, myrcene, quercetin, rosmarinic and chlorogenic acids SS was prepared, they were chromatographed under the conditions mentioned above and possibility of carrying out the quantitative analysis of the given substances within the concentrations range from 0.1 to $1 \mathrm{mg} / \mathrm{ml}$ was shown. At the second stage of the research the content of each component was calculated according to the chromatograms of the solutions studied with SS addition and without it.

The quantitative content (\%) of the basic compounds identified in the apiphytomedicine developed and its separate constituents is given in Tab. 2. 


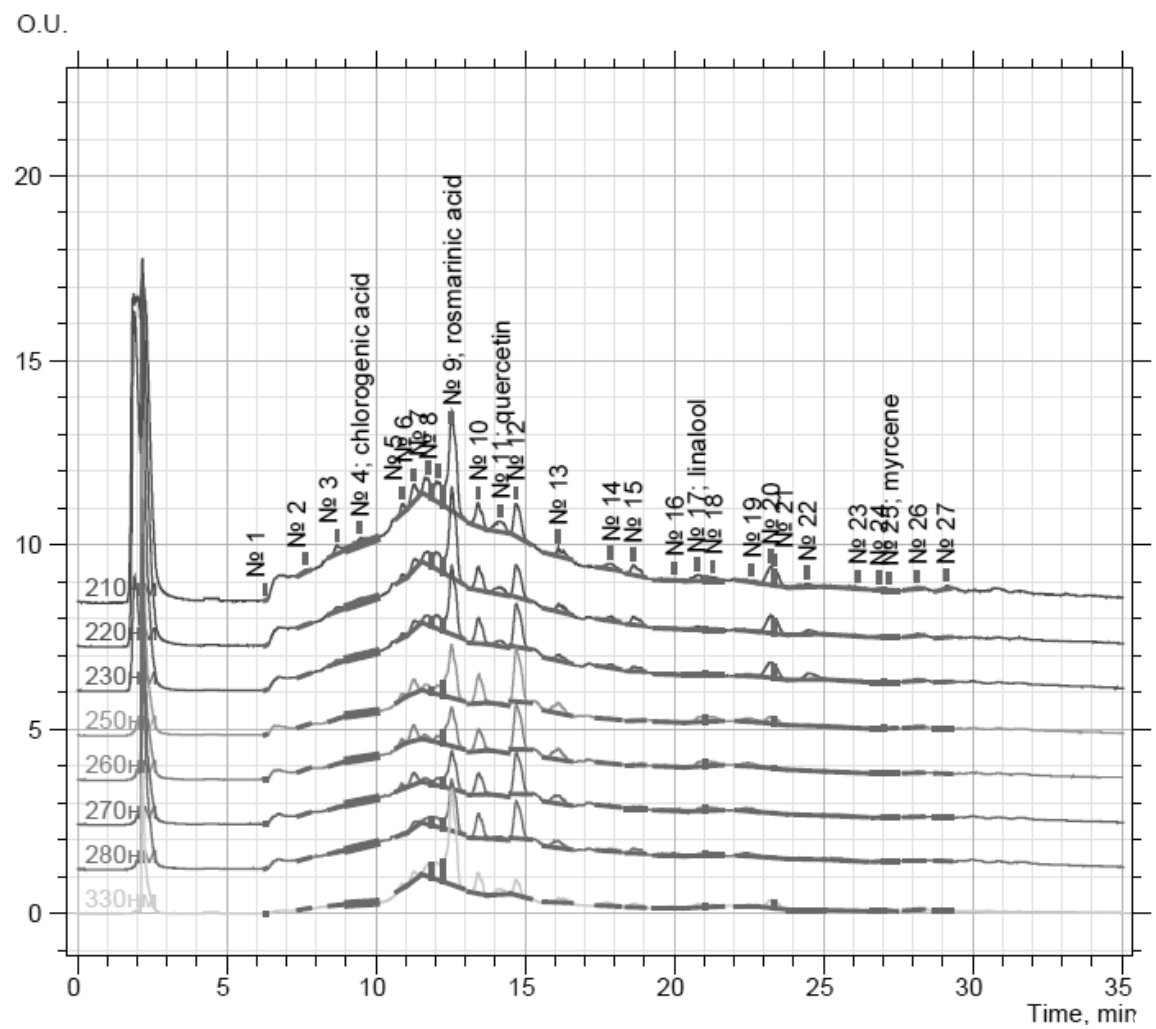

Fig. The typical chromatogram of biologically active compounds of "Apised" capsules obtained by the HPLC method under the conditions mentioned above.

Table 2

The results of the quantitative determination of linalool, myrcene, rosmarinic acid, quercetin and chlorogenic acid by the HPLC method

\begin{tabular}{|c|c|c|c|}
\hline \multirow{2}{*}{ Compound } & \multicolumn{2}{|c|}{ Peak area } & \multirow{2}{*}{ Content, \% } \\
\hline & $S$ & $S_{a d}$ & \\
\hline \multicolumn{4}{|c|}{ Garden balm herb } \\
\hline Linalool & 0.18146 & 0.32645 & $0.18 \%$ \\
\hline Rosmarinic acid & 0.22210 & 0.44618 & $1.71 \%$ \\
\hline Chlorogenic acid & 0.13256 & 0.23589 & $0.16 \%$ \\
\hline \multicolumn{4}{|c|}{ Hop cones } \\
\hline Quercetin & 0.32156 & 0.48957 & $0.21 \%$ \\
\hline Myrcene & 0.21387 & 0.44782 & $0.12 \%$ \\
\hline \multicolumn{4}{|c|}{ Inflorescences of spike lavender } \\
\hline Linalool & 0.12065 & 0.26048 & $0.12 \%$ \\
\hline \multicolumn{4}{|c|}{ natural powdered honey } \\
\hline Myrcene & 0.30102 & 0.44782 & $0.19 \%$ \\
\hline Linalool & 0.11018 & 0.24536 & $0.11 \%$ \\
\hline \multicolumn{4}{|c|}{ "Apised" capsules } \\
\hline Linalool & 0.14618 & 0.28128 & $0.14 \%$ \\
\hline Rosmarinic acid & 0.06121 & 0.28947 & $0.45 \%$ \\
\hline Chlorogenic acid & 0.05875 & 0.15245 & $0.07 \%$ \\
\hline Quercetin & 0.09548 & 0.26518 & $0.06 \%$ \\
\hline Myrcene & 0.15425 & 0.30007 & $0.09 \%$ \\
\hline
\end{tabular}

It should be noted that the experimental data of Tab. 2 concerning the percentage of biologically active compounds determined in the apiphytomedicine "Apised" correlate well with the composition of the medicine developed and the literary information about the chemical composition of the medicinal plant raw material studied $[3,4,8]$.

Thus, the complex of the experimental research conducted concerning identification and quantitative determination of biologically active substances of APhI of the apiphytomedicine developed allows to develop the reliable and reproducible method, which gives the possibility to carry out standardization of "Apised" capsules developed.

\section{CONCLUSIONS}

1. The qualitative composition and quantitative content of the complex apiphytomedicine "Apised" developed in the form of capsules for treatment of mental and emotional disorders and depression states in sports medicine has been investigated using HPLC-analyser on the basis of a Milichrome A-02 chromatograph.

2. The presence of 27 compounds has been detected in the composition of the "Apised" apiphytomedicine developed; among them linalool, myrcene, rosmarinic acid, quercetin and chlorogenic acid have been identified.

3 . The method offered gives the possibility to carry out standardization of the composition of the medicine developed, namely "Apised"capsules, regardless of the way of obtaining and origin of the medicinal plant raw material with the help of high-performance liquid chromatography. 


\section{REFERENCES}

1. Барам Г.И., Болотов В.В., Изотов Б.Н. и др. // Журн. хроматограф. общества. - 2004. - T. IV, №1. C. $11-20$.

2. Пат. 77952 Украӥна, МПК (2006.01) А 61 K 9/48, А 61 Р 25/20. Лікувально-профілактичний засіб у формі капсул із седативною дією / О.С.Шпичак, О.І.Тихонов. - № и 2012 05333. - Заявл.: 15. 01. 2013. Опубл.: 11. 03. 2013. - Бюл. №5. - 5 с.

3. Попова Н.В., Литвиненко В.И. Лекарственные растения мировой флоры. - Х.: СПДФО Мосякин В.Н., 2008. $-510 \mathrm{c}$.

4. Приймак Г.М. Продукти бджільництва та лікарські рослини в народній медищині. - К.: IАЕ УААН, 2001. $-530 \mathrm{c}$.

5. Шпичак О.С., Яковлєва Л.В., Шаповал О.М. // Укр. біофармаи. журн. - 2012. - №5-6 (22-23). - С. 78-83.

6. European Pharmacopoeia / European Directorate for the Quality of Medicines (EDQM). $-6^{\text {th }}$ ed. - Council of Europe, 2007. - 3308 .

7. Fanali S., Haddad P.R., Poole C. et al. Liquid Chromatography: Applications. - Elsevier, 2013. - 683 p.

8. Heinrich M., Barnes J., Gibbons S., Heinrich M. Fundamentals of Pharmacognosy and Phytotherapy. - London: Churchill Livingstone, 2004. - 309 p.

9. McMaster M.C. HPLC, a practical user's guide. $-2^{\text {nd }}$ ed. - John Wiley \& Sons, Inc., 2007. -239 p.

10. Moldoveanu S.C., David V. Essentials in Modern HPLC Separations. - Elsevier, 2013. - 533 p.

11. Shpychak O.S., Tikhonov O.I., Khanin V.A. // News of Pharmacy. - 2013. - №4 (76). - P. 23-27.

12. Snyder L.R., Kirkland J.J., Dolan J.W. Introduction in modern liquid chromatography. - 3rd ed. - John Wiley \& Sons, Inc., 2010. - 957 p.

\section{ДОСЛІДЖЕННЯ СКЛАДУ АКТИВНИХ ФАРМАЦЕВТИЧНИХ ІНГРЕДІЄНТІВ КАПСУЛ «АПІСЕД» МЕТОДОМ ВИСОКОЕФЕКТИВНОЇ РІДИННОЇ ХРОМАТОГРАФІЇ \\ О.С.Шпичак, O.І.Тихонов}

Ключові слова: терпеноїди; фрлавоноїди; високоефективна рідинна хроматографрія

З огляду на те, що найбільщ оптимальним методом для якісного та кількісного аналізу багатокомпонентних лікарських засобів, у тому числі і фітопрепаратів, є метод високоефективної рідинної хроматографрії - завдяки можливості ідентифрікувати та кількісно визначати в одній пробі речовини різного ступеня леткості, досліджено якісний склад та кількісний вміст розробленого комплексного апіфрітопрепарату «Апісед» у форомі капсул для застосування у спортивній медицині з використанням «BEPX-аналізатора» на основі хроматографра «Міліхром А-02». На попередньому етапі досліджень активних фрармацевтичних інгредієнтів капсул «Апісед» та безпосередньо розробленого апіфрітопрепарату було встановлено наявність 14 сполук у складі стандартизованої субстанції меду натурального порошкоподібного, 19 сполук - трави меліси лікарської, 24 сполуки - шишок хмелю звичайного, 20 сполук - суцвіть лаванди вузьколистої, 27 сполук - капсул «Апісед». Шляхом порівняння часу утримування та спектральних відношень отриманих піків з «базою даних» приладу було показано присутність у складі трави меліси лікарської ліналоолу, розмаринової та хлорогенової кислот, шишок хмелю звичайного - кверцетину та мірцену, суцвіть лаванди вузьколистої - ліналоолу, меду натурального порошкоподібного - ліналоолу та мірцену. Експериментальні дані щодо відсоткового вмісту біологічно активних речовин в апіфрітопрепараті "Апісед» добре корелюють зі складом розробленого препарату та літературними даними відносно хімічного складу досліджуваної лікарської рослинної сировини. Запропонована методика дає можливість незалежно від способу отримання та походження лікарської рослинної сировини провести стандартизацію складу розробленого препарату - капсул «Апісед».

\section{ИССЛЕДОВАНИЕ СОСТАВА АКТИВНЫХ ФАРМАЦЕВТИЧЕСКИХ ИНГРЕДИЕНТОВ КАПСУЛ «АПИСЕД» МЕТОДОМ ВЫСОКОЭФФЕКТИВНОЙ ЖИДКОСТНОЙ ХРОМАТОГРАФИИ О.С.Шпичак, А.И.Тихонов}

Ключевые слова: терпеноиды; фрлавоноиды; высокоэффрективная жидкостная хроматографиия

Ввиду того, что наиболее оптимальным методом для качественного и количественного анализа многокомпонентных лекарственных средств, в том числе и фритопрепаратов, является метод высокоэфффективной жидкостной хроматографрии - благодаря возможности идентифрицировать и количественно определять в одной пробе вещества разной степени летучести, исследован качественный состав и количественное содержание разработанного комплексного апифитопрепарата «Аписед» в форме капсул для применения в спортивной медицине с применением «ВЭЖХ-анализатора» на основе хроматографра «Милихром А-02». На предварительном этапе исследований активных фармацевтических ингредиентов кап- 
сул «Аписед» и непосредственно разработанного апифитопрепарата было установлено наличие 14 соединений в составе стандартизированной субстанции меда натурального порошкообразного, 19 соединений - травы мелиссы лекарственной, 24 соединения - шишек хмеля обыкновенного, 20 соединений - соцветий лаванды узколистой, 27 соединений - капсул «Аписед». Путем сравнения времени удерживания и спектральных отношений полученных пиков с «базой данных» прибора было показано присутствие в составе травы мелиссы лекарственной линалоола, розмариновой и хлорогеновой кислот, шишек хмеля обыкновенного - кверцетина и мирцена, соцветий лаванды узколистой - линалоола, меда натурального порошкообразного - линалоола и мирцена. Экспериментальные данные относительно процентного содержания биологически активных веществ в апифитопрепарате "Аписед» хорошо коррелируют с составом разработанного препарата и литературными данными относительно химического состава исследуемого лекарственного растительного сырья. Предложенная методика дает возможность независимо от способа получения и происхождения лекарственного растительного сырья провести стандартизацию состава разработанного препарата - капсул «Аписед». 